\title{
Recenzje
}

Piotr Siemaszko, Od akademizmu do ekspresjonizmu. Sugestie pikturalne $w$ poezji polskiej końca XIX i początków XX wieku, Wydawnictwo Uniwersytetu Kazimierza Wielkiego, Bydgoszcz 2007

\section{Poezja młodopolska w kontekście stylów i prądów malarskich}

Piotr Siemaszko od dawna zajmuje się problemami sztuk plastycznych i związkami literatury $\mathrm{z}$ malarstwem. W ostatnim dziesięcioleciu opublikował na ten temat trzy książki: Zmienność $i$ trwanie. O eseistyce Zbigniewa Herberta (Bydgoszcz, 1996), Świat obrazu - obraz świata. Przestrzenie pograniczne w pisarstwie G. Herlinga-Grudzińskiego, Z. Herberta i J. Czapskiego (Bydgoszcz, 2000) oraz Od akademizmu do ekspresjonizmu. Sugestie pikturalne $w$ poezji polskiej końca XIX $i$ początków $X X$ wieku (Bydgoszcz, 2007). Pragnę podkreślić, że relacje między sztukami badał w różny sposób, próbował wielu dróg, jakby szukał odpowiedniej dla siebie metody. Toteż każda z jego prac przedstawiała ten problem inaczej. Książka Zmienność $i$ trwanie. O eseistyce Zbigniewa Herberta ukazywała eseje o sztuce w szerokich kontekstach myśli filozoficznej. Znaleźli się tam jońscy filozofowie przyrody i filozofowie nowożytni (Nietzsche, Bergson, Wittgenstein), a także sławni kulturoznawcy (Spengler i Huizinga). Filozoficzny zamysł całości podkreślała kompozycja pracy, poszczególne rozdziały zostały bowiem poświęcone kolejno problemom ontologicznym, epistemologicznym i etycznym. Późniejsi interpretatorzy Herberta szli jego śladami, niejednokrotnie rozwijali wątki przez niego wskazane, jak związki z myślą starożytną czy Nietzschem. Warto także podkreślić, że praca Piotra Siemaszki dotyczyła wprawdzie esejów, ale w toku rozważań Autor odwoływał się również do wierszy, potraktował twórczość Herberta jako spójną całość i pokazał podstawowe antynomie w niej obecne, jak dionizyjskość i apollińskość, chaos i ład, ratio i doświadczenie zmysłowe, intuicję i epifanię itp. A na koniec, w ostatnim rozdziale rozprawy, szczegółowo określił miejsce Herberta we współczesnej eseistyce - obok Herlinga-Grudzińskiego, Stempowskiego, Miłosza, Jastruna, Iwaszkiewicza i Międzyrzeckiego. Ukazał Herberta wszechstronnie - nie tylko na tle filozoficznym, ale i na tle historycznoli- 
terackim, w szerokiej panoramie najwybitniejszych przedstawicieli polskiej eseistyki. Dopowiedzeniem i uzupełnieniem książki o eseistyce Herberta jest rozprawa zamieszczona w następnej książce - Świat obra$z u-o b r a z$ świata, zatytułowana $W$ strone ideału. O Zbigniewie Herbercie. Siemaszko zajął się w niej problematyką ściśle malarską: poglądami poety na temat światła, koloru, linii i kompozycji. Konteksty malarskie pozwalają ukazać preferencje Herberta i jego „ulubieńców”, jak Piero della Francesca czy Vermeer oraz wyciągnąć wnioski dotyczące estetyki Herberta klasyka, wielbiciela harmonii i geometrii, przeciwnika ujęć ekspresjonistycznych i emocjonalnych.

W książce Świat obrazu - obraz świata Siemaszko analizował funkcję dzieła sztuki w twórczości Herlinga-Grudzińskiego. Interesowała go także postać Józefa Czapskiego jako malarza i jego ewolucja twórcza od koloryzmu do znaczeń symbolicznych. Próbował więc różnych dróg badawczych i z wielu sposobów badania korespondencji sztuk wybrał na koniec jedną - „malarską”. Jej właśnie poświęcił obszerną pracę Od akademizmu do ekspresjonizmu. Sugestie pikturalne $w$ poezji polskiej końca XIX i poczatków XX wieku. Jednym słowem skoncentrował się na analizie problematyki malarskiej w literaturze: wrażliwości na kolor, światło, kontur rysunku, perspektywę i kompozycję. Idzie zatem wyraźnie śladami wielkich poprzedników: Heinricha Wölfflina, a przede wszystkim Oskara Walzela, który mówił o „wzajemnym oświetlaniu się sztuk” i dowodził, że od wieku XIX malarstwo odgrywało rolę wiodącą w sztuce i w literaturze. Tam właśnie, w malarstwie, rodziła się nowa wrażliwość, powstawały nowe prądy, które swoją obecność zaznaczały nie tylko na terenie sztuk plastycznych. To przekonanie o jedności sztuk podziela Piotr Siemaszko. W literaturze i malarstwie tropi wspólne tematy, motywy, analogiczny stosunek do natury, a przede wszystkim te same nastroje i malarskie techniki w opisach literackich.

Wychodząc od malarstwa jako sztuki wiodącej, Siemaszko terenem swojej badawczej penetracji uczynił literaturę Młodej Polski. Sądzę, że ta decyzja jest wyjątkowo trafna. Właśnie w tym okresie powstawały i współistniały nowe kierunki w sztuce: impresjonizm (który stanowił rewolucję na terenie malarstwa), ekspresjonizm i symbolizm. Dlatego książka nosi tytuł Od akademizmu do ekspresjonizmu... i skomponowana jest „po kierunkach” malarskich przełomu wieków, a jej poszczególne rozdziały omawiają literackie mutacje czterech najważniejszych nurtów w ówczesnej sztuce: akademizmu (rozdział „Wzorzec akademicki”, czyli idea piękna zmysłowego), symbolizmu (Od konkretu do abstrakcji, czyli gdy sztuka poddaje się nastrojom), impresjonizmu (Supremacja koloru i światta. Od naturalizmu do impresjonizmu) i ekspresjonizmu (Dyna- 
mika, deformacje, dysonanse. O wyobraźni wizualnej młodopolskiego preekspresjonizmu). Autor najpierw wnikliwie charakteryzuje każdy z wymienionych nurtów, pokazuje jego źródła estetyczne, cytuje programy i manifesty, omawia twórczość plastyczną wybitnych przedstawicieli, a na koniec - przytacza egzemplifikację literacką. Toteż jego praca jest erudycyjna, źródłowa i dobrze osadzona w historii malarstwa przełomu wieków. Prócz erudycji zwraca także uwagę staranna, rzec można nawet, luksusowa szata graficzna książki. Siemaszko nie tylko pisze o obrazach, ale je przedstawia na licznych, miniaturowych ilustracjach, włamanych w tekst rozprawy. Doskonały papier i kolor powodują, że mimo małych rozmiarów reprodukcje są czytelne. Cieszą oko i uczą. Ponadto każda ilustracja, jak i każde przywołanie dzieła plastycznego w tekście rozprawy zawierają informację, gdzie, w jakim muzeum znajduje się oryginał. Obok arcydzieł malarstwa Autor zamieszcza także reprodukcje ilustracji publikowanych wówczas w „Tygodniku Ilustrowanym”. Jest to bardzo dobry pomysł pokazujący gust epoki. Wszystko to sprawia, że dokumentacyjna wartość książki budzi najwyższe uznanie.

Uznanie budzi także obfita egzemplifikacja literaturoznawcza, sięganie do utworów obcych, głównie francuskich i angielskich, co wymownie pokazuje europejskie korzenie naszej kultury. Wśród ogromnej rzeszy wielokrotnie cytowanych poetów młodopolskich znaleźli się także Asnyk i Konopnicka - kolejny dowód rzetelnej postawy Autora, który pokazuje tym samym, jak wielokształtne było życie literackie epoki przemian, w której mieszały się prądy i głosy różnych pokoleń. Ale przede wszystkim książka Siemaszki pokazuje różne techniki literackie, którymi posługiwali się ci sami poeci (jak np. Kasprowicz), wskazuje wątki tradycji literackiej, do której poszczególne prądy nawiązywały. Wszystko to sprawia, że rozważania są mocno osadzone nie tylko w kontekstach malarskich, ale również w kontekście historycznoliterackim.

Kończy rozprawę stosunkowo krótki, syntetyczny rozdział Kontynuacje $i$ modyfikacje, czyli „efekt młodopolski” $w$ poezji dwudziestolecia międzywojennego, w którym Autor nie poprzestaje na „kontynuacjach”, ale kreśli panoramę nowych kierunków i nowych tematów, które zaistniały w międzywojniu (nowa estetyka, groteska, „pożegnanie z przedmiotem", surrealizm). Można nawet powiedzieć, że bardziej interesuje go szukanie nowych „prądowych” pokrewieństw niż obserwowanie sposobu funkcjonowania „starych” młodopolskich technik malarskich.

Czy wobec tego nie ma rysy na świetnej pracy Piotra Siemaszki? Zauważyłam taką rysę, jest nią zbyt daleko posunięta ostrożność w przyjmowaniu teoretycznych założeń, określaniu celów i formułowaniu wniosków. Bogata egzemplifikacja historycznoliteracka zgromadzona przez

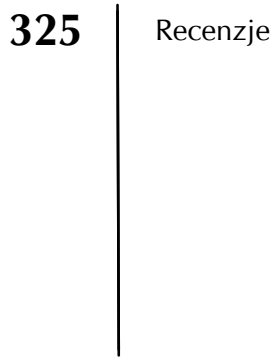


Autora nie zostaje wykorzystana do szerszej refleksji nad problemami poetyki czy też mechanizmami procesu historycznoliterackiego. I tak wniosek kończący obszerne i kompetentne rozważania o filiacjach literatury i malarstwa na przełomie XIX i XX wieku jest więcej niż skromny, dotyczy „wzrokocentrycznego charakteru kultury modernizmu” (s. 277). Sądzę, że zgromadzony materiał daje doskonałą okazję do głębszej refleksji na temat stylów, prądów i kierunków literackich. Tymczasem Autor ostrożnie mówi tylko o „sugestiach pikturalnych”, takie też określenie znalazło się w podtytule książki. Ale nasuwa się tu pytanie, co to takiego te „sugestie pikturalne”? Z wyjaśnień wstępnych wynika, że to „malarsko ukształtowany język opisu” (s. 14) czy też dokładniej: „poetycko zorganizowane elementy (pojedyncze słowa lub zespoły leksykalno-semantyczne)" (s. 15). A więc w gruncie rzeczy chodzi o styl. Tylko dlaczego stylu nie nazwać stylem? A jeżeli nie jest to styl, to czym się sugestia pikturalna od stylu różni? Kiedy mamy do czynienia jedynie z „sugestią", kiedy można mówić o „stylu”, a kiedy termin „styl” nie wystarcza i zjawisko zdobywa status prądu literackiego? A kiedy ten status traci? Sądzę, że te wszystkie komplikacje Autor mógł doskonale pokazać na przykładzie ekspresjonizmu. Na podstawie swoich badań pokusić się o umiejscowienie polskiego ekspresjonizmu w procesie historycznoliterackim. Jednym słowem rozstrzygnąć kontrowersyjny problem czasowej lokalizacji (i związanej z tym terminologii), z którym badacze zmagają się od lat.

Ekspresjonizm został w rozprawie potraktowany nie jako „sugestia pikturalna” czy styl, lecz właśnie jako prąd - z okresu międzywojnia. Siemaszko mówi bowiem konsekwentnie o „młodopolskim preekspresjonizmie", sugerując tym samym, że w Młodej Polsce mamy zapowiedź zjawiska, które rozwinie się później. I rzeczywiście, termin „ekspresjonizm" pojawia się dopiero w rozdziale o dwudziestoleciu. Jednakże egzemplifikacja przytoczona w książce podważa moim zdaniem taką koncepcję prądu. Pokazuje, że nowe i oryginalne jest właśnie to, co zostało nazwane „młodopolskim preekspresjonizmem” - twórczość Micińskiego, Kasprowicza i Przybyszewskiego. Natomiast ekspresjonizm dwudziestolecia jest scharakteryzowany jako wtórny, co Autor podkreśla, powołując się w przypisie na sąd Jerzego Kwiatkowskiego, że ciekawsze przykłady ekspresjonizmu spotkać można nie w „Zdroju”, ale u Skamandrytów. Więcej nawet: konstatując „tradycjonalizm i młodopolskie obciążenia”, pokazuje, że ekspresjonizm wchodzi w symbiozę z futuryzmem i surrealizmem. A więc traci tożsamość! Przestaje funkcjonować jako prąd, funkcjonuje w dwudziestoleciu jako styl...

Nie mogę zgodzić się $\mathrm{z}$ sądem, że w dwudziestoleciu impresjonizm ulega wyczerpaniu (s. 255). „Wyczerpaniu” uległa jedynie konwencjonal-

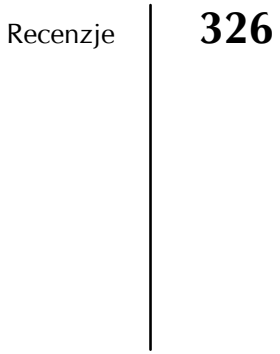


na, młodopolska gama kolorystyczna, ale nie mechanizmy „wrażeniowego" opisu. Impresjonistyczny opis przeniknął do prozy dwudziestolecia, o czym pisała Barbara Sienkiewicz, analizując Przygode $w$ nieznanym kraju Anieli Gruszeckiej ${ }^{1}$. Króluje także w niedocenianych powojennych powieściach Andrzeja Kuśniewicza, na co zwracała uwagę Bożena Witosz². Wyraźnie zaznaczył się także w prozie lat dziewięćdziesiątych, co starałam się pokazać na przykładzie Hanemanna i Ester Stefana Chwi$\mathrm{na}^{3}$. Ale relacje między poezją a prozą i „przechodzenie” obrazowania z poezji na teren prozy - to już odrębny problem teoretyczny, który wykracza poza zakres recenzowanej rozprawy.

Prace Piotra Siemaszki koncentrują się na problematyce szeroko pojętej korespondencji sztuk. Jego ostatnia książka Od akademizmu do ekspresjonizmu. Sugestie pikturalne w poezji polskiej końca XIX i poczatków XX wieku, poświęcona związkom poezji i malarstwa w okresie Młodej Polski, jest szeroko zakrojoną monografią i pokazuje tę problematykę w sposób kompleksowy. Ze względu na wysoki poziom merytoryczny i bogactwo egzemplifikacji, a także piękną szatę graficzną może stanowić wzór dla rozpraw interdyscyplinarnych.

Seweryna Wysłouch

1 Zob. B. Sienkiewicz, Literackie „teorie widzenia” $w$ prozie dwudziestolecia międzywojennego, Poznań 1992.

2 Zob. B. Witosz, Kilka uwag o opisie we wspótczesnej powieści (na przykładzie prozy A. Kuśniewicza), „Prace językoznawcze 19. Studia polonistyczne”, red. A. Kowalska, A. Wilkoń, Katowice 1991.

${ }^{3}$ Zob. S. Wysłouch, Inny opis? Wizualizacja a problem epickości (na przykt. polskiej prozy lat 90.), [w:] Dwudziestowieczna ikonosfera $w$ literaturach europejskich, red. B. Tokarz, Katowice 2002. 